\title{
Do Renal Tumor Characteristics Affect the Number of Hemostatic Agents Used During Partial Nephrectomy?
}

\author{
Böbrek Tümörü Özellikleri Parsiyel Nefrektomi Sırasında Kullanılan Hemostatik Ajan Sayısını \\ Etkiler mi?
}

\author{
(D) Erdem Kısa1, (1) Mehmet Zeynel Keskin1, (1) Hilal Şahin2 , (1) Cem Yücel11, (1) Mehmet Yiğit Yalçın1, (1) Özgür Çakmak1, \\ (D) Yusuf Özlem İlbey ${ }^{1}$ \\ 1 University of Health Sciences Tepecik Training and Research Hospital, Clinic of Urology, Izmir, Turkiye \\ 2 University of Health Sciences Tepecik Training and Research Hospital, Clinic of Radiology, Izmir, Turkiye
}

\section{What's known on the subject? and What does the study add?}

Hemostatic agents (HAs) are frequently used worldwide to achieve hemostasis during partial nephrectomy (PN). Cellulose based agents $(78.8 \%)$ and polytetrafluoroethylene pledgets (38\%) are the more commonly used HAs during the PN in our clinic. There is no publication that shows the relationship of the number of HAs used with tumor size, RENAL nephrometry score, ischemia time, and tumor pathology results. Therefore, despite our limitations, our work is valuable in this respect.

\begin{abstract}
Objective: The aim of this study was to investigate the use and types of hemostatic agents (HAs) used during partial nephrectomy (PN) and the relationship of the number of these agents used during surgery with tumor size, RENAL nephrometry score (NS), peroperative ischemia time, and postoperative pathology results.

Materials and Methods: Records of patients, who had undergone PN in our clinic due to renal mass between January 2013 and February 2019 , were retrospectively reviewed. Our study included 71 patients who were administered one or more HAs during PN. Demographic characteristics, operative data, and pathological results of patients, who were administered one or more HAs during PN, were recorded.

Results: Cellulose-based agents and polytetrafluoroethylene pledgets were the most frequently used HAs (78.8\% and 38\%, respectively). The patients were divided into two groups according to tumor size (0-4 cm and larger than $4 \mathrm{~cm}$ tumors), RENAL NS (low and intermediate-high score), ischemia time (0-20 min and longer than $20 \mathrm{~min})$, and tumor pathology result (benign and malignant tumor), and the number of HAs used in each group was compared. When the groups were compared separately in terms of number of HAs used, no statistically significant difference was found between the groups ( $p=0.323, p=0.183, p=0.618$, and $p=0.131$, respectively).

Conclusion: HAs are frequently used in our clinic to achieve hemostasis. There was no statistically significant difference in the number of HAs used between the groups.

Keywords: Renal mass, Partial nephrectomy, Hemostatic agents

Öz

Amaç: Çalışmamızın amacı parsiyel nefrektomi (PN) operasyonu sırasında hemostatik ajan (HA) kullanımının yaygınlığı ve bu kullanılan HA sayısının hastaların tümör boyutu, RENAL nefrometri skoru (NS), iskemi zamanı ve tümör patoloji sonucu ile ilişkisini araştırmaktır.

Gereç ve Yöntem: Kliniğimizde renal kitle nedeniyle Ocak 2013 - Şubat 2019 tarihleri arasında PN operasyonu geçiren hastaların kayıtları tarandı. PN sırasında HA kullanılan 71 hasta çalışmaya dahil edildi. PN sırasında HA kullanılan hastaların demografik özellikleri, operasyon bilgileri, patolojik sonuçları ve komplikasyonları kaydedildi.
\end{abstract}

Correspondence: Erdem Kısa MD, University of Health Sciences Tepecik Training and Research Hospital, Department of Urology, İzmir, Turkiye Phone: +90 5052234221 E-mail: drerdemkisa@hotmail.com ORCID-ID: orcid.org/0000-0002-4728-3808

Received: 02.04.2019 Accepted: 01.05.2019

Cite this article as: Kısa E, Keskin MZ, Şahin H, Yücel C, Yalçın MY, Çakmak Ö, İlbey YÖ. Do renal tumor characteristics affect the number of hemostatic agents used during partial nephrectomy? J Urol Surg 2019;6(3):225-230.

๑Copyright 2019 by the Association of Urological Surgery / Journal of Urological Surgery published by Galenos Publishing House. 
Bulgular: Selüloz bazlı ajanlar (\%78,8) ve politetrafloroetilen pledgets (\%38) PN sırasında en sık kullanılan HA'lardır. Tümör boyutu (0-4 cm ve 4 cm'den büyük tümorler), RENAL NS (düşük puan-orta puan-yüksek puan), iskemi süresi (0-20 dk ve $20 \mathrm{dk}$ 'dan uzun iskemi süresi) ve tümör patoloji sonucu (benign tümör-malign tümör), kendi içerisinde gruplara ayrıldı ve gruplar içerisinde kullanılan HA sayıları karşılaştırıldı. Kullanılan HA sayısı açısından gruplar ayrı ayrı karşılaştıııldığında, gruplar arasında istatistiksel anlamlı fark saptanmamıştır $(p=0,323, p=0,183, p=0,618, p=0,131$ sirasıyla).

Sonuç: HA'lar PN sırasında hemostaz aşamasında kliniğimizde çok sık kullanıımaktadır. Çalışma grupları arasında, PN sırasında kullanılan HA sayısı açısından istatistiksel fark saptanmamıştır.

Anahtar Kelimeler: Renal kitle, Parsiyel nefrektomi, Hemostatik ajanlar

\section{Introduction}

Partial nephrectomy (PN) surgery, including open partial nephrectomy (OPN), laparoscopic partial nephrectomy (LPN) and robotic partial nephrectomy (RPN), are favored for the management of T1 masses when technically feasible (1). Bleeding is among the most important complications associated with this surgery. While the rate of this complication is $1.6 \%$ following OPN, it is 4-6\% after LPN $(2,3)$. The most important stage at which bleeding can be prevented is ensuring good hemostasis during surgery. At this stage, various hemostatic agents (HAs) are utilized either alone or in combination with hemostatic suturing of the excision base in order to make hemostasis safer and minimize the bleeding complication. These HAs have been used in renal surgery for 40 years and they act by mimicking, facilitating, or bypassing certain steps of the coagulation cascade $(4,5)$ (Figure 1).

HAs are commonly used throughout the world in both OPN and LPN $(6,7)$. Multicenter studies conducted in Europe and the United States have determined the rates of using at least one HA in OPN or LPN to be between $67.5 \%$ and $86 \%(6,7)$. Some of these agents facilitate hemostasis during surgery, while others contribute to renography by filling the parenchymal defect created by tumor excision in addition to facilitating hemostasis $(5,8,9)$. On the other hand, other studies have stated that HA use did not cause a difference in the bleeding complication and could only have an effect in cases of minor bleeding $(6,7)$. Some recent studies argue that HAs do not have any effect on bleeding complication rates $(10,11,12,13,14)$.

This study aims to investigate the use and types of HAs used during PN and the relationship of the number of these agents used during surgery with tumor size, nephrometry score (NS), peroperative ischemia time, and postoperative pathology results.

\section{Materials and Methods}

Records of 91 patients, who had undergone OPN or LPN operation in our clinic due to renal mass between January 2013 and February 2019, were retrospectively reviewed. A retrospective review and analysis was performed following the approval of the institutional ethics committee. Patients who had not been administered HA during PN $(n=8)$, and patients whose imaging records were incomplete $(n=12)$ were excluded from the study. Demographic characteristics, operative data, pathological results, and complications of patients, who were administered one or more HAs during the PN operation, were recorded. Two urologists (E.K. and M.Y.Y) used preoperative contrast-enhanced abdominal computed tomography (CT) or magnetic resonance imaging (diffusion-weighted imaging and/or dynamic contrastenhanced imaging) images to determine RENAL NSs. The results were crosschecked and confirmed by an uro-radiologist (H.S.). The masses were classified into low, intermediate, and high-risk tumors based on RENAL. NSs as suggested by Kutikov et al. (15). The types and number of HAs used during surgery, as well as the total number of HAs used were recorded.

\section{Open Partial Nephrectomy or Laparoscopic Partial Nephrectomy Surgical Technique and the Use of Hemostatic Agent}

The decision for choosing OPN or LPN was determined according to the RENAL NS and surgeon's experience. During the PN, both the renal artery and the renal vein were dissected and prepared. Only the renal artery was clamped during warm ischemia. The tumor was excised with cold scissors and removed en-bloc. After removal of the mass, excision bed hemostasis was achieved with absorbable sutures (2.0 vicryl). The collecting system was checked for leaks and if present, the leaks were closed with absorbable sutures (3.0 vicryl). The excision cavity was then filled with either a cellulose-based agent (Surgicel$^{\circledR}$; Ethicon, Somerville, NJ, USA), gelatin-based sponge (Spongostan ${ }^{\circledR}$ (Ferrosan, Copenhagen, Denmark), fibrin sealant (Tachosil ${ }^{\circledR}$; Nycomed, Zurich, Switzerland) or autologous perirenal fat, based on the surgeon's choice and the size of the cavity. Polytetrafluoroethylene (PTFE) pledgets (Syneture ${ }^{\circledR}$; Covedien, Mansfield, MA) were used during the renal parenchymal approximation to prevent sutures from tearing the parenchyma and then the renography was completed. In addition, Weck Hem-o-lok clips (Weck Closure Systems Research, Triangle Park, $\mathrm{NC}$ ) were used during suturing and parenchymal approximation in LPN. Then, in case of need and based on the surgeon's choice, either hemostatic powder (Bloodcare powder ${ }^{\circledR}$; Life Line, Brno, Czech Republic) or adhesives (Bioglue ${ }^{\circledR}$; CryoLife, Kennesaw, 
GA, USA) alone or in combination were used on the renography area. After the reconstruction was completed, the arterial clamp was removed and after the bleeding control, the procedure was completed.

\section{Statistical Analysis}

The groups were assessed for normal distribution using the Shapiro-Wilk test. None of the evaluated parameters was normally distributed. The Mann-Whitney $U$ test was used for pairwise comparisons and the Kruskal-Wallis Test was used for three or more groups. A p value of less than 0.05 was considered statistically significant. All analyses were made using the IBM SPSS V22.

\section{Results}

Our study included 71 patients who were administered one or more HAs during the PN operation. The patients' demographic

Table 1. Patient Characteristics

\begin{tabular}{|c|c|}
\hline Number of patients & 71 \\
\hline Median age, year (min-max.) & $62(63-77)$ \\
\hline Mean \pm SD & $59.1 \pm 13.6$ \\
\hline \multicolumn{2}{|l|}{ Sex $n,(\%)$} \\
\hline Male & $42(59.1 \%)$ \\
\hline Female & $29(40.8 \%)$ \\
\hline \multicolumn{2}{|l|}{ Operation side $n,(\%)$} \\
\hline Right & $30(42.2 \%)$ \\
\hline Left & $41(57.7 \%)$ \\
\hline \multicolumn{2}{|l|}{ Renal tumor location $n,(\%)$} \\
\hline Anterior & $37(52.1 \%)$ \\
\hline Posterior & $34(47.8 \%)$ \\
\hline Upper pole & $14(19.7 \%)$ \\
\hline Mid pole & $28(39.4 \%)$ \\
\hline Lower pole & $29(40.8 \%)$ \\
\hline \multirow{2}{*}{$\begin{array}{l}\text { Median preoperative renal tumor size, } \mathrm{cm} \\
\text { (min-max.) }\end{array}$} & $3.5(1-15)$ \\
\hline & $4.2 \pm 2.3$ \\
\hline \multicolumn{2}{|l|}{ Mean \pm SD } \\
\hline Median RENAL N.S, (min-max.) & $6(4-12)$ \\
\hline Mean \pm SD & $6.3 \pm 2.1$ \\
\hline \multicolumn{2}{|l|}{ RENAL N.S } \\
\hline Low & $40(56.3 \%)$ \\
\hline Intermediate & $24(33.8 \%)$ \\
\hline High & $7(9.8 \%)$ \\
\hline \multicolumn{2}{|l|}{ Operation type } \\
\hline Open & $63(88.7 \%)$ \\
\hline Laparoscopic & $8(11.2 \%)$ \\
\hline Median HA used, min. (min-max) & $2(1-7)$ \\
\hline Mean \pm SD & $2.5 \pm 1.4$ \\
\hline
\end{tabular}

characteristics, operative data, pathology results, and complications are summarized in Table 1.

Patients and HAs Used: The types and distribution of HAs used during the PN operations are summarized in Table 2. In 35.2\% of cases, single HA was sufficient for achieving hemostasis. Two HAs were needed in $28.1 \%$ and 3 or more additional HAs were needed in $36.6 \%$ of the patients. Cellulose-based agents (Surgice ${ }^{\circledR}$ ) and PTFE pledgets (Syneture ${ }^{\circledR}$; Covedien, Mansfield, $\mathrm{MA})$ were the most frequently used HAs during PN (78.8\% and $38 \%$, respectively).

The patients were divided into two groups based on tumor size (0-4 $\mathrm{cm}$ and larger than $4 \mathrm{~cm}$ tumors), RENAL NS (low and intermediate-high score), ischemia time (0-20 min and longer than $20 \mathrm{~min}$ ), and tumor pathology result (benignmalignant tumor) and the number of HAs used in each group was compared. When the groups were compared separately in terms of the number of HAs used, no statistically significant

Table 1 contiuned

\begin{tabular}{ll}
\hline Median operative time, min. (min-max) & $140(100-350)$ \\
Mean \pm SD & $154.4 \pm 47.6$ \\
\hline Median ischemia time, min. (min-max) & $11(0-45)$ \\
Mean \pm SD & $12 \pm 11.1$ \\
\hline Median hospitalization time, day, (min-max) & $3(2-14)$ \\
Mean \pm SD & $3.7 \pm 1.7$ \\
\hline Pathology & \\
Benign & $15(21.1 \%)$ \\
- Oncocytoma & $7(9.8 \%)$ \\
- Angiomyolipoma & $3(4.2 \%)$ \\
- Simple Cyst & $1(1.4 \%)$ \\
- Chronic Pyelonephritis & $2(2.8 \%)$ \\
- Hydatid Cyst & $2(2.8 \%)$ \\
& \\
Malignant & $56(78.8 \%)$ \\
- Clear cell type & $35(49.2 \%)$ \\
- Papillary type 1 & $7(9.8 \%)$ \\
- Papillary type 2 & $1(1.4 \%)$ \\
- Chromophobe type & $11(15.4 \%)$ \\
- Multilocularcyst type & $2(2.8 \%)$ \\
\hline Complications & \\
Intraoperative complications & $1(1.4 \%)$ \\
- Transfusion & $1(1.4 \%)$ \\
- Pleural injury & \\
- Ureteral injury & \\
- Fragmentation of renal mass & $1(1.4 \%)$ \\
Postoperative complications & $1(8.4 \%)$ \\
- Urinary leakage, DJ stent & \\
- Arteriovenous fistula, embolization & \\
- Urinary Tract Infection & \\
\hline SD: Standard deviation HA: Hemostatic agent, NS: Nephrometry score, min: Minimum, \\
max: Maximum
\end{tabular}


Table 2. Patients and hemostatic agents used

\begin{tabular}{ll}
\hline Hemostatic agents & $\mathbf{n},(\%)$ \\
\hline - Fibrin sealant (Tachosil $\left.{ }^{\circledR}\right)$ & $3(4.2 \%)$ \\
- Cellulose based agents (Surgicel $\left.^{\circledR}\right)$ & $56(78.8 \%)$ \\
- Gelatin based sponge (Spongostan $\left.^{\circledR}\right)$ & $9(12.6 \%)$ \\
- Gelatin based sealent (FloSeal $\left.{ }^{\circledR}\right)$ & $4(5.6 \%)$ \\
- Adhesives (Bioglue $\left.{ }^{\circledR}\right)$ & $17(23.9 \%)$ \\
- Hemostatic powder (Bloodcare powder & $16(22.5 \%)$ \\
-Autologous perirenal fat & $12(16.9 \%)$ \\
- Hem-O clips & $8(11.2 \%)$ \\
- Metal clips & $8(11.2 \%)$ \\
- PTFE pledgets (PLEDGETS & \\
\hline
\end{tabular}

PTFE: Polytetrafluoroethylene

Table 3. Comparison of groups in terms of number of hemostatic agents used

\begin{tabular}{lll}
\hline & Number of HA used & $\mathbf{p}$ \\
\hline $\begin{array}{l}\text { Median (01-03), preoperative } \\
\text { renal tumor size }\end{array}$ & $2(1-3)$ & \\
$0-4 \mathrm{~cm}$ & $3(1-4)$ & 0.323 \\
$>4 \mathrm{~cm}$ & & \\
\hline Median (01-03), RENAL N.S & & \\
Low & $2(1-3)$ & 0.183 \\
Intermediate & $2(1.25-4)$ & \\
High & $3(2-3)$ & \\
\hline Median (01-03), ischemia time & & \\
$0-20$ min & $2(1-3.75)$ & \\
$>20$ min & $2(1.75-3.25)$ & 0.131 \\
\hline Median (01-03), pathology & & \\
Benign & $3(2-4)$ & \\
Malignant & $2(1-3)$ & \\
\hline
\end{tabular}

HA: Hemostatic agent, NS: Nephrometry score

difference was found between the groups $(p=0.323, p=0.183$, $p=0.618$, and $p=0.131$, respectively) (Table 3 ).

\section{Discussion}

It has been shown that in renal mass treatment, PN results in better protection of the renal reserve and decreases the risk of metabolic and cardiovascular disorders compared to radical nephrectomy (16). During PN, after the tumor is excised, the important step is to quickly control bleeding by providing a good hemostasis in order to see surgical margins clearly and to achieve reconstruction of the renal parenchyma in a shorter time. HAs have been in use for many years for the purpose of accelerating and facilitating the hemostasis stage in both the open, laparoscopic, and robotic types of PN (6-14). In a multicenter study conducted by Lang et al. (6) in France, at least one HA was used in OPN or LPN surgery at a rate of $71.4 \%$. Again, a multi-center study conducted by Breda et al. (7) in the
United States and Europe determined that 16 of 18 centers used HAs and $80 \%$ of surgeons at these centers used HAs during LPN. In the study that we performed at our clinic, the rate of HA use in OPN or LPN surgery was $91.2 \%$. All LPN cases involved one or more HAs. We associate our frequent use of HAs during PN to the fact that approximately $45 \%$ of the renal masses we treated with PN had an RENAL. NS categorized as intermediate-high score.

Previous studies in the literature have shown the association between ischemia time and NSs such as RENAL., preoperative aspects and dimensions used for an anatomical, C-index, and diameter-axial-polar during PN $(15,17,18,19)$. In a study comparing these NSs, RENAL. NS has been shown to be most correlated with ischemia time, tumor margin and occurrence of complications during PN (20). In this study, we divided the patients based on tumor size $(0-4 \mathrm{~cm}$ and larger than $4 \mathrm{~cm}$ tumors), RENAL NS (low -intermediate-high score), ischemia time (0-20 min and longer than $20 \mathrm{~min})$, and tumor pathology result (benign-malignant tumor) and compared the number of HAs used among these groups. Although the groups such as tumor size greater than $4 \mathrm{~cm}$, higher RENAL score, ischemia time longer than $20 \mathrm{~min}$, and malignant pathology were expected to have higher HA use, there was no statistically significant difference between the groups. We believe that the technique and effectiveness of the suture applied to the excision base during surgery comprises the most important step for hemostasis, as stressed in recent studies, and is the reason we did not observe significant difference between the groups. Secondly, HAs used for hemostasis can be applied in combination with bipolar coagulation or Harmonic/LigaSure. Lastly, identifying the relationship between the number of HAs used and the evaluated parameters was complicated due to the heterogeneity created by the variability in different surgeons' HA preferences.

HAs have been used in PN surgery for many years. It was stressed that these agents had potential benefits associated with decreasing complications, such as bleeding and urinary leakage, and shortening ischemia time in both laparoscopic and robotic surgery $(8,9)$. Meanwhile, years of accumulated experience and advances in suture techniques called the hemostatic effect of these HAs into question. Some studies conducted in the recent years suggested that HAs had a very limited contribution to hemostasis or had no contribution at all $(6,7,10,11,12,13,14)$. In these publications, the authors emphasized that suturing after tumor excision comprised the most important step in hemostasia rather than the use of HAs. They stated that the effect attributed to HAs in earlier studies decreased due to advanced surgical experience and suturing techniques, and therefore, with regard to the bleeding complication, there were no differences between the cases where HAs were used 
and where HAs were not used $(10,11,12,13,14)$. Moreover, they suggested that the cost that emerges due to the use of these agents, their effectiveness and their safety must also be taken into consideration (6). In this study, we were not able to perform a statistical comparison between the group operated with HAs and the group operated without HAs in terms of complications such as bleeding and urinary leakage because the number of patients operated without HAs was very low $(n=6,7.7 \%)$. However, based on our experience in PN surgery, during the OPN or LPN, HAs help to achieve hemostasis after tumor excision, to fill the cavity after tumor excision, and to prevent sutures from tearing the parenchyma during the approximation of the parenchyma. We still believe that hemostasis suture thrown into the tumor base at the hemostasis stage is the most important step in terms of bleeding control and that HAs play more of a supportive and complementary role.

\section{Study Limitations}

The limitations of this study can be listed as the lack of randomization in the study design, its retrospective nature, and being a single-center study. Moreover, the inability to standardize the selection of HA types based on tumor characteristics, evaluating procedures performed by various surgeons, as well as heterogeneity of HAs, and variation in dimensions of the HAs (Surgice ${ }^{\circledR}$, Spongostan ${ }^{\circledR}$ and PTFE Pledgets) may be listed as limitations. The strengths of this study include the fact that, to our knowledge, it is the first study that has evaluated the relationship of the number of HAs used during PN with tumor size, RENAL NS, ischemia time, and renal mass pathology.

\section{Conclusion}

PN is a standardized method in the treatment of small renal masses. The most important stage of PN is hemostasis. HAs are frequently used worldwide and in our clinic to achieve hemostasis. Although the groups such as tumor size greater than $4 \mathrm{~cm}$, higher RENAL score, ischemia time longer than 20 min, and malignant pathology were expected to have higher HA use, there was no statistically significant difference between the groups. However, future prospective randomized controlled studies are needed to strengthen our findings.

\section{Ethics}

Ethics Committee Approval: A retrospective review and analysis was performed following the approval of the institutional ethics committee.

Informed Consent: All patients had given written informed consent before the surgery for giving permission for the use of the collected data at any time.

Peer-review: Externally peer-reviewed.

\section{Authorship Contributions}

Surgical and Medical Practices: E.K, M.Z.K., M.Y.Y., C.Y., Ö.Ç., Y.Ö.I., Concept: E.K., H.Ş Design: E.K., H.Ş, Data Collection and/ or Processing: E.K., M.Z.K., H.S., M.Y.Y., C.Y., Ö.Ç., Analysis and/ or Interpretation: E.K., M.Z.K., H.Ş., M.Y.Y., C.Y., Ö.Ç., Y.Ö.I., Literature Research: E.K, H.Ş, Ö.Ç Writing: E.K.

Conflict of Interest: No conflict of interest was declared by the authors.

Financial Disclosure: The authors declared that this study received no financial support.

\section{References}

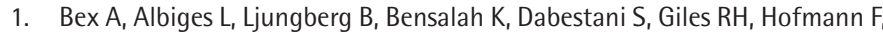
Hora M, Kuczyk MA, Lam TB, Marconi L, Merseburger AS, Staehler M, Volpe A, Powles T. Updated European Association of Urology Guidelines Regarding Adjuvant Therapy for Renal Cell Carcinoma. Eur Urol 2017;71:719-722.

2. Gill IS, Kavoussi LR, Lane BR, Blute ML, Babineau D, Colombo JR Jr, Frank I, Permpongkosol S, Weight CJ, Kaouk JH, Kattan MW, Novick AC. Comparison of 1,800 laparoscopic and open partial nephrectomies for single renal tumors. J Urol 2007;178:41-46.

3. Ramani AP, Desai MM, Steinberg AP, Ng CS, Abreu SC, Kaouk JH, Finelli A, Novick AC, Gill IS. Complications of laparoscopic partial nephrectomy in 200 cases. J Urol 2005;173:42-47.

4. Urlesberger $\mathrm{H}$, Rauchenwald $\mathrm{K}$, Henning $\mathrm{K}$. Fibrin adhesives in surgery of the renal parenchyma. Eur Urol 1979;5:260-261.

5. Galanakis I, Vasdev N, Soomro N. A review of current hemostatic agents and tissue sealants used in laparoscopic partial nephrectomy. Rev Urol 2011;13:131-138.

6. Lang $\mathrm{H}$, Mouracade $\mathrm{P}$, Gimel $\mathrm{P}$, Bernhard JC, Pignot G, Zini L, Crepel $M$, Rigaud J, Salomon L, Bellec L, Vaessen C, Roupret M, Jung JL, Mourey E, Martin X, Bigot P, Bruyère F, Berger J, Ansieau JP, Salome F, Hubert J, Pfister C, Trifard F, Gigante M, Baumert H, Méjean A, Patard JJ. National prospective study on the use of local haemostatic agents during partial nephrectomy. BJU Int 2014;113:56-61.

7. Breda A, Stepanian SV, Lam JS, Liao JC, Gill IS, Colombo JR, Guazzoni G, Stifelman MD, Perry KT, Celia A, Breda G, Fornara P, Jackman SV, Rosales A, Palou J, Grasso M, Pansadoro V, Disanto V, Porpiglia F, Milani C, Abbou CC, Gaston R, Janetschek G, Soomro NA, De la Rosette JJ, Laguna PM, Schulam PG . Use of Haemostatic Agents and Glues during Laparoscopic Partial Nephrectomy: A Multi-Institutional Survey from the United States and Europe of 1347 Cases. Eur Urol 2007;52:798-803.

8. Richter F, Schnorr D, Deger S, Trk I, Roigas J, Wille A, Loening SA. Improvement of hemostasis in open and laparoscopically performed partial nephrectomy using a gelatin matrix-thrombin tissue sealant (FloSeal). Urology 2003;61:73-77.

9. Morelli L, Morelli J, Palmeri M, D'Isidoro C, Kauffmann EF, Tartaglia D, Caprili G, Pisano R, Guadagni S, Di Franco G, Di Candio G, Mosca F. Robotic surgery and hemostatic agents in partial nephrectomy: a high rate of success without vascular clamping. J Robot Surg 2015;9:215-222.

10. Carrion DM, SA YG, Rivas JG, Bazan AA, Sebastian JD, Martinez-Pineiro L. The role of hemostatic agents in preventing complications in laparoscopic partial nephrectomy. Cent European J Urol 2017;70:362-367.

11. Abu-Ghanem Y, Dotan Z, Kaver I, Zilberman DE, Ramon J. The use of Haemostatic Agents does not impact the rate of hemorrhagic complications in patients under going partial nephrectomy for renal masses. Sci Rep 2016;6:32376. 
12. Maurice MJ, Ramirez D, Kara Ö, Malkoç E, Nelson RJ, Caputo PA, Kaouk JH. Omission of Hemostatic Agents During Robotic Partial Nephrectomy Does Not Increase Postoperative Bleeding Risk. J Endourol 2016;30:877-883.

13. Peyronnet $B$, Oger $E$, Khene Z, Verhoest $G$, Mathieu R, Roumiguié $M$, Beauval $J B$, Pradere B, Masson-Lecomte A, Vaessen C, Baumert H, Bernhard JC, Doumerc N, Droupy S, Bruyere F, De La Taille A, Roupret M, Bensalah K. The use of hemostatic agents does not prevent hemorrhagic complications of robotic partial nephrectomy. World J Urol 2015;33:1815-1820.

14. Antonelli A, Minervini A, Mari A, Bertolo R, Bianchi G, Lapini $A$, Longo $N$ Martorana G, Mirone V, Morgia G, Novara G, Porpiglia F, Rocco B, Rovereto B, Schiavina R, Simeone C, Sodano M, Terrone C, Ficarra V, Carini M, Serni S; RECORd Project-LUNA Foundation. Tri Match comparison of the efficacy of FloSeal versus TachoSil versus no hemostatic agents for partial nephrectomy: results from a large multicenter dataset. Int J Urol 2015;22:47-52.

15. Kutikov A, Uzzo RG. The R.E.N.A.L. nephrometry score: a comprehensive standardized system for quantitating renal tumor size, location and depth. J Urol 2009;182:844-853.

16. Thompson RH, Boorjian SA, Lohse CM, Leibovich BC, Kwon ED, Cheville JC, Blute ML. Radical nephrectomy for $\mathrm{pT} 1 \mathrm{a}$ renal masses may be associated with decreased overall survival compared with partial nephrectomy. J Urol 2008;179:468-471.

17. Ficarra V, Novara G, Secco S, Macchi V, Porzionato A, De Caro R, Artibani W. Preoperative aspects and dimensions used for an anatomical (PADUA) classification of renal tumours in patients who are candidates for nephronsparing surgery. EurUrol 2009;56:786-793.

18. Simmons MN, Ching CB, Samplaski MK, Park CH, Gill IS. Kidney tumor location measurement using the C index method. J Urol 2010;183:17081713.

19. Simmons MN, Hillyer SP, Lee BH, Fergany AF, Kaouk J, Campbell SC . Diameteraxial-polar nephrometry: integration and optimization of R.E.N.A.L. and centrality index scoring systems. J Urol 2012;188:384-390.

20. Borgmann $H$, Reiss AK, Kurosch M, Filmann N, Frees S, Mager R, Tsaur I, Haferkamp A. R.E.N.A.L. Score Outperforms PADUA Score, C-Index and DAP Score for Outcome Prediction of Nephron Sparing Surgery in a Selected Cohort. J Urol 2016;196:664-671. 